\section{Similarity in membrane proteins}

SIR--Adams and Pollard' recently discovered that the nonfilamentous myosins IA and IB of Acanthamoeba can bind to membranes, a finding with important implications concerning the role of these proteins in cell motility. We would like to draw attention to a 50-amino-acid domain in the sequence of the myosin-IB isozyme ${ }^{2}$ that is shared with a diverse family of cyto- two proteins of another single-celled eukaryote, Saccharomyces cerevisiae. The fus1 protein on the cell membrane is essential for cell fusion during mating ${ }^{6.7}$; cdc25 is a regulator of the membrane associated adenylyl cyclase. The $\mathrm{SH} 3$ motif is, therefore, shared by membraneassociated proteins of both single-celled and higher eukaryotes. This conservation

\begin{tabular}{|c|c|c|}
\hline Myosin-1B & (983) & ALYYFFRENPDE--- -LTFNEGRUUTU I -NKSNPDWWEGEL----NGQR-GUFPASYUELI -PR \\
\hline Fodrin- $\alpha$ & (974) & ALYOyqeksPrE-----uTmkkGdilTII-Nst NkDWWkuEu--.-Ndrq-G fuPAaYUkk I-dp \\
\hline PLC148 & (798) & AL fDykAqreDE-----LTFtksAi i qnu-eKqeggWWrGdyh---hkkq-I wFPsnYUEemu-s \\
\hline$v-\mathrm{Crk}$ & (375) & --LpFkkGdilkir-dKpeeqWWnaEdm---dGkR-Gm iPupYUEkcrPs \\
\hline $\mathrm{C}-\mathrm{Fgr}$ & (84) & ALYDyefrteDd-----LTFtkGekfhi I-Nnt egDWWEars/s--sGkt-Gc i PsnYUapu-ds \\
\hline Lsk & (67) & ALhsyepshdgd-----LgFekGeq|ri I-eqS-gellhkaqs|t--tGQe-G fiPf nfUaka-ns \\
\hline c-Yes & (97) & AL YDyefirt ted- - - LsFkkGer fqiI -Nnt egDWwEars ia--tGkn-Gy i PsnYUapa-ds \\
\hline Hck & $(62)$ & ALYDyeA ihred-----LsFqkGdqmuUI-eea-gelWkarsla--tke-Gy PsnYUaru-ns \\
\hline c-Src & (88) & ALYDyesrtetd-----LsFkkGer I qiu-NntegDWhI ahsIt--tGQt-Gy i PsnYUaps-ds \\
\hline C-Abl & (68) & ALYDFuAsgdnt-----LsitkGekIrUIgynhHgedcEaqtk---NGQ--GwuPsnYitpu-ns \\
\hline fus 1 & (443) & viqDyeprit DE-----irisIGekuk i t-atht dgWcluqke---NtQk-GsihuSuddkry In \\
\hline cdc25 & (64) & AaYOFnypikkdsssqILsuqqGet iyil-NKnssgWhdG I viddsNGkurGwFPqnfgrplrds \\
\hline \multirow[t]{2}{*}{ Consensus } & & RLYDY \\
\hline & & $\begin{array}{clll}F & E & E & F\end{array}$ \\
\hline
\end{tabular}

Upper-case letters denote identity with the myosin-IB sequence. The amino-acid number of the first residue of each sequence is given in parentheses. $\phi$ signifies hydrophobic residues. The PIR database was searched using the programs Prosearch (J. Collins and A. Coulson, University of Edinburgh) on an AMT DAP, and AMPS (G. Barton and M.J.E.S.) on a VAX 8700; the Genepro program (Riverside Scientific, Seattle) was used to search the EMBL database.

plasmic proteins, many of which are associated with the plasma membrane (see figure). This domain, called $\mathrm{SH} 3$ or the Abox, was first described as a region of sequence similarity between the nonreceptor protein-tyrosine kinases, the 148K phospholipase C (PLC), and the $\mathrm{v}$-crk oncogene of the avian sarcoma virus CT10 (refs 3 and 4). It was subsequently found in the $\alpha$-chain of the non-erythroid spectrin homologue, fodrin".

Our database searches have also

\section{Retrocitation}

SIR-In my News and Views article "Reverse Transcriptases. Retrons in Bacteria" (ref. 1) I stated "no such reverse transcriptase seemed to exist in bacteria“. M. Beljanski has since called my attention to his publications on reverse transcriptase in bacteria ${ }^{2-5}$. This work was confirmed in several Soviet publications $^{\text {n.-4 }}$. It will he of interest to see if these activities are related to retrons.

HOWARD M. TEMIN

McArdle Laboratory,

University of Wisconsin.

Madison, Wisconsin 53706, USA

1. Temin, H.M. Nature 339, 254-255 (1989).

Beljanski, M. C. r. hebd. Séanc. Acad. Sci. Paris D274. 2801-2804 (1972)

3. Beljanski, M. C. r. hebd. Séanc. Acad. Sci. Paris D276, $1625-1628(1973)$

4. Beljanski, M. \& Beljanski, M. Biochem. Genet. 17. 163-180 (1974)

5. Beljanski, M., Bourgarel, P. \& Beljanski, M.S. C. r. hebd Séanc. Acad. Sci., Paris D286, 1825-1828 (1978)

Romashchenko, A.G. et al. Dokl. Akad. Nauk SSSR 233 734-737 (1977)

7. Lushniknva, T.P. et al. Molec. Biol. 12, 1163-1171 (1978)

8. Vorob eva, N.V. et al. Molec. Biol. 16, 977-983 (1982)

9. Grabkina, O.A. et al. Molec. Biol. 17. 830-838 (1983) revealed $\mathrm{SH} 3$ domains in cdc 25 and fus1 indicates a basic function common to all eukaryotes but this function is still a mystery. Although SH3 is found in many proteins at the cell periphery, it is not universal; it is absent from erythroid spectrin for instance.

Adams and Pollard mapped the membrane-binding region of myosin-IA to a $100 \mathrm{~K} \mathrm{~N}$-terminal chymotryptic fragment, but the binding region of myosin-IB has not yet been localized. Intriguingly, the $\mathrm{SH} 3$ domain of the IB protein is close to the protein's ATP-independent actinbinding site ${ }^{8}$. It will be interesting to see whether the SH3 domains of myosin-IB and other proteins play a role in binding either directly to membranes or to the submembrane cytoskeleton.

ADAM R. F. RODAWAY

MiCHAEL J. E. STERnBERG DAVID L. BENTLEY

ICRF Laboratory,

Lincoln's Inn Fields,

London, WC2A 3PX, UK

1. Adams. R. \& Pollard, T. Nature 340, 565-568 (1989)

2. Jung, G. Korn, E. \& Hammer, J Proc natn. Acad Sci. U.S.A. 84. 6720-6724 (1987).

Stahl, M., Ferenz, C., Kelleher, K., Kriz, R. \& Knopf, J. Nature 332, 269-272 (1988)

4. Mayer, B., Hamaguchi. M., \& Hanafusa, H. Nature 332 272-274 (1988)

5. Wasenius, V. et al. J. cell. Biol. 108, 79-93 (1989)

6. Truehart, J. Boeke, J. \& Fink, G. Molec cell. Biol. 7. 2316-2328 (1987)

7. McCaffrey, G., Clay, F., Kelsay, K. \& Sprague, G. Molec. cell. Biol. 7, 2680-2690 (1987)

8. Lynch, T. et al. J. biol. Chem. 261, 17156 (1986)

D. Marth, J., Pect, R. Krebs, E \& Perlmutter, R. Cell 43 393-404 (1985)

1. Sukegawa, J. et al. Molec. cell. Biol. 7, 41-47 (1987)

12. Klemsz, M., McKercher, S. \& Maki, R. Nucleic Acids Res. 15. 9600 (1987).

13. Takeya, T. \& Hanafusa, H. Cell 32, 881-890 (1983)

4. Shtivelman, E., Lifshitz, B., Gale, R., Roe, B. \& Canaani, E. Cell 47, 277-284 (1986)

15. Broek, D. et al. Cell 48, 789-799(1987).
9. Katamine, S., et al. Molec, cell. Biol. 8, 259-266 (1988).

\section{What are males good for?}

SIR-Successful rearing of young in most birds requires the care of two adults. Such parental pairs are almost always a male and a female, but the discovery of female/female pairings in one tern, one goose and several gull species, discussed by Jared Diamond ${ }^{1}$, demonstrates that other parental pairing combinations are possible. Female/female pairs are, nevertheless, rare even in these few species ${ }^{2-6}$. Determining the reasons why they are so uncommon may help to formulate answers for the old question 'What are males good for?'

The most obvious benefit to females of pairing with a male - access to a source of sperm - is probably not of primary importance, as females paired together still copulate with unmated and mated males ${ }^{7}$. Female/female pairs, therefore, produce fertile eggs, although their fertility rates may be less than those of male/female pairs ${ }^{+-6}$.

Perhaps a more important advantage provided by males is that of a territory. Female birds are generally smaller than males, and may, therefore, be at a disadvantage when competing against a male for a territory. In all the colonies where I have found female/female pairs or the unusually large (5-7 egg) clutches that result from them ${ }^{2.8}$ (eight ring-billed gull colonies, four California gull colonies and a Caspian tern colony), space for more nesting pairs was available on the nesting islands. In western gulls, female/female pairs were found in one colony where there was little competition for breeding space, but no such pairs were found in another colony where breeding space was limited".

Probably the most important advantage a female derives from pairing with a male is the opportunity to raise only her own young (nest parasitism aside). By contrast, each female in a homosexual pair will contribute, on average, only half the young. An unrelated pair of females must, therefore, produce twice the offspring of a heterosexual pair before the reproductive output of each homosexually paired female equals that of a

1. Diamond, J.M. Nature 340, 101 (1989).

2. Conover, M.R. Condor 86, 467-471 (1984)

Conover M.R. Wilson Bull 96, 249-267 (1984)

4. Hunt, G. . J. \& \& Hunt, M.W. Science 196, 1466-1467 (1977).

5. Kovacs, K.M. \& Rycer, J.P. Auk 100, 658-669 (1983).

6. Quinn, T.W. et al. Auk 106, 177-184 (1989).

7. Fitch, M.A. \& Shugart, G.W. Am. Nat. 124, 116-126 (1984).

8. Conover, M.R. Condor 85, 346-349 (1983).

9. Pierotti, R. Auk 98, 532-549 (1981)

10. Lagrenade, M. \& Mousseau, P. Auk 100, 658-669 (1983).

11. Hunt, G.L. Jr et al. Auk 97, 473-479 (1980)

12. Conover, M.R. \& Hunt, G.L. Jr Condor 86, 472-476 (1984)

13. Conover, M.R \& Hunt G.L. Jr Wilson Bull 96, 619-625 (1984).

NATURE · VOL 342 · 7 DECEMBER 1989 